\title{
A szíriai polgárháború vége? Az újjáépítés gazdasági és politikai lehetöségei
}

Az Aszad-rezsim által 2019 decemberében a felkelők által ellenőrzött ldlib visszafoglalására indított offenzíva a polgárháború katonai szakaszának utolsó fejezetét jelentheti. Az elkövetkező időszakban nagyobb figyelmet kap a politikai rendezés kérdése, illetve a gazdasági újjáépítés. A szíriai konfliktusban érintett szereplök közül a jelentősebb geopolitikai súllyal bíró államok (Oroszország, Irán) nem rendelkeznek kellő gazdasági erőforrással a szíriai újjáépités kapcsán. Ezzel szemben a geopolitikailag jelenleg kevésbé meghatározó államok (Amerikai Egyesült Államok, Európai Unió és az Öböl Menti Együttmüködési Tanács államai) akadályozhatják az újjáépités folyamatát. A tanulmány célja, hogy rámutasson az elmúlt évek politikai és gazdasági folyamataira, valamint a szíriai konfliktus geopolitikai és geoökonómiai összefüggéseire. Az Aszad-rezsim az elmúlt időszakban egy olyan háborús gazdaságot hozott létre, amely politikai figurák, üzletemberek és helyi katonai milíciák szövetségére épitve egy múködőképes állami modellt alkotott. Mindennek a fenntartása és támogatása nem érdeke sem a nyugati államoknak, sem számos regionális szereplőnek. Emellett azonban az Aszad-rezsimmel való kapcsolatok vonatkozásában a korábban ellenséges államok pragmatikus kapcsolatokat próbálnak kialakitani, amelynek egyik példája az Egyesült Arab Emirátusok, amely újranyitotta damaszkuszi diplomáciai képviseletét. Az elkövetkező években Szíria vonatkozásában tovább folytatódik a geoökonómiai rivalizálás, amely a konfliktus megoldását is kétségessé teszi.

Kulcsszavak: Szíria, asztanai folyamat, alkotmányozóbizottság, újjáépítés, geoökonómiai konfliktus

\section{Csicsmann László: End of the Syrian Civil War? The Economic and Political Opportunities of the Reconstruction}

The recent offensive by the Assad regime against the rebel-held territories in Idlib could be the last chapter of the military phase in the Syrian civil war. In the forthcoming period, political solution and economic reconstruction would be given increased attention. Among the actors involved in the Syrian conflict, the states with larger geopolitical influence (Russia and Iran) do not have enough economic assets to cover the bill of the reconstruction. On the other hand, the states with a lesser geopolitical weight (United States, European Union and the members of the Gulf Cooperation Council) could block the reconstruction process in Syria. The paper is aimed at analysing the recent political and economic development as well as exploring the geopolitical and geoeconomic factors of the Syrian conflict.

The Assad regime, building on a coalition of political figures, new businessmen and local militias, has developed a functioning war economy and political model, the support of which is not in the interest of the Western states or some regional actors. However, certain states formerly hostile with the Assad regime, have recently developed pragmatic relations with Damascus, as, for example, the United Arab Emirates, which recently reopened its diplomatic mission in Syria. In the coming 
years, the geopolitical and geoeconomic rivalry could prevent any kind of solution of the Syrian civil war.

Keywords: Syria, Astana process, Constitutional Committee, reconstruction, geoeconomic conflict

\section{Bevezetés}

A 2020-as év elején - az immáron a tizedik évébe lépő szíriai konfliktus - a Moszkva támogatását élvező Aszad-rezsim idlibi offenzívájának következtében új fejezetéhez érkezett. ${ }^{1}$ Az elemzők szerint ugyanis a közvetlen katonai összecsapást, amely egyszerre viseli magán a háború és a polgárháború jegyeit a konfliktusnak egy újabb síkja, az újjáépítésért folyó geoökonómiai jellegü szembenállás váltja fel. Egy, a globális és regionális szereplők beavatkozásával járó fegyveres konfliktus politikai rendezése általában akkor lehetséges, ha a részt vevő felek között minimális konszenzus van a lezárást illetően. A szíriai konfliktus komplexitását figyelembe véve az elmúlt kilenc esztendőben ilyen minimális konszenzus nem állt fenn, és az is kétséges, hogy a közeljövőben kialakul. A háború és a polgárháború elmúlt lassan egy évtizede alatt az egyes állami és nem állami szereplök célrendszerei is átalakultak, mondhatni folyamatosan változtak a katonai erőviszonyok alakulásával párhuzamosan. A politikai rendezés általában akkor kerül előtérbe, ha valamelyik globális vagy regionális szereplő úgy alakítja a katonai erőviszonyokat, hogy az kedvező feltételeket teremtsen egy esetleges politikai rendezés irányába. A klasszikusnak számító Carl von Clausewitz A háborúról írott, híres munkájában az alábbiakban fogalmazza meg a háború természetét: „a politika szüli a háborút; a politika: az értelem, a háború: pusztán csak eszköz és nem megfordítva".

A 2020-as év azért is tűnik fordulópontnak Szíria vonatkozásában, mert az elemzők szerint az Aszad-rezsim, ha nem is megnyerte, de „túlélte” a polgárháborút, amelynek az ország számára és a régió számára is komoly következményei lesznek. ${ }^{3}$ A globális aktorok közül az Amerikai Egyesült Államok (a továbbiakban: Egyesült Államok) világossá tette, hogy nem kíván mélyrehatóan foglalkozni a szíriai politikai rendezés és újjáépítés kérdéseivel, és azt lényegében átengedte Oroszországnak. ${ }^{4}$ Putyin Oroszországa pedig él a befolyásszerzés lehetőségével, amely megnyilvánul az elmúlt évek politikai és katonai aktivitásában is. A regionális szereplők azonban érdemben kívánják befolyásolni a szíriai válság alakulását: Irán, Izrael és Törökország közvetlen résztvevője a konfliktusnak, és számos más, elsősorban arab állam pedig közvetetten próbálja érdekeit érvényesíteni. Oroszország pedig élve a lehetöséggel mindent elkövet, hogy az Aszad-ellenes felkelöket visszaszorítsa. Mindez azonban nem jelenti azt, hogy az Aszad-rezsim narratívája teljes mértékben érvényesülne. Az Aszad-rezsim ugyanis azt próbálja elhitetni a nemzetközi közösséggel, hogy

\footnotetext{
1 Jelen publikáció az Európai Unió, Magyarország és az Európai Szociális Alap társfinanszírozása által biztosított forrásból az EFOP-3.6.3-VEKOP-16-2017-00007 azonosítószámú „Tehetségből fiatal kutató” - A kutatói életpályát támogató tevékenységek a felsőoktatásban című projekt keretében jött létre.

Carl von Clausewitz: A háborúról, Göttinger Kiadó, Veszprém, 1999, 551. o.

Lina Кнатів: Bashar al-Assad's Hollow Victory, [online], 2020. 01. 17. Forrás: Foreign Affairs [2020. 04. 01.]

Eyal Zisser: The End of the Syrian Civil War. The Many Implications, Middle East Quarterly, Summer 2019, 7. o.
} 
az alapvetően külső beavatkozás eredményeként kialakult polgárháború véget ért, és minden visszaállítható a 2011. március elötti időszaknak megfelelően. Ez a percepció azért is téves, mert ahogy Lina Khatib megfogalmazza: Szíria és az országot támogató Oroszország, illetve Irán közötti kapcsolatrendszer a partnerségből kliensi viszonnyá alakult át. ${ }^{5}$ Ez egyben azt is jelenti, hogy Szíria további sorsa Oroszország és kisebb részben Irán, valamint Törökország kezébe került.

Jelen tanulmány célja, hogy a 2020-ban kialakult katonai erőviszonyokat figyelembe véve elemezze a szíriai konfliktus egyes belső és külső szereplőinek az újjáépítéssel kapcsolatosan artikulált érdekeit. Az elemzés különös tekintettel veszi számba az olyan vitás kérdéseket, mint a szíriai menekültek jövőjét, a Szíria föderalista alapon való átszervezésének dilemmáját vagy a gazdasági rekonstrukció problémáját. A tanulmány azt a hipotézist fogalmazza meg, hogy az Iszlám Állam legyőzésével és ezzel párhuzamosan az Egyesült Államok szíriai szerepének csökkenésével Oroszország törekvései a meghatározók a politikai rendezés kapcsán. Oroszország pedig a szíriai kérdés általa mediált részleges politikai rendezésében érdekelt, amelynek központi elemét képezi az Aszad-rezsim prolongálása.

\section{A katonai helyzet az Idlib elleni offenzívát megelőzően}

Jelen sorok írásakor ${ }^{6}$ az Iszlám Állam elveszítette területi szuverenitását (2019 márciusában Bágúz visszafoglalása), és Szíria katonai szempontból négy területre osztható fel az alábbiak szerint:

1. A legnagyobb területi kiterjedést 2018-2019 óta az Aszad-rezsim által ellenőrzött területek teszik ki. Az Aszad-rezsim narratívája szerint visszaállt minden a régi kerékvágásba, vagyis orosz és iráni segítséggel sikerült helyreállítani a 2011 előtti viszonyokat. Ez a dominánsnak is nevezett narratíva egyre meghatározóbb, ugyanakkor elfedi a valóságot és a kérdés komplexitását. Az Aszad-rezsim ellenőrzi a legsürübben lakott településeket (Damaszkusz-Homsz-Hama-Aleppó-tengely). A rezsim magát legitimnek tartja, hiszen a 2014-es - kétséges körülmények között megtartott - elnökválasztás eredményeként újabb hét esztendőre bebiztosította hatalmát. A következő elnökválasztás 2021-ben esedékes, és az alkotmányt figyelembe véve Aszad elnök utolsó ciklusa lehet. ${ }^{7}$ Az Aszad-rezsim narratívája csak kis részben állja meg a helyét, ugyanis az a komplex politikai rendszer, amely - többek között - a szunnita arab kereskedőcsaládok támogatására is épült, mára nem létezik. Ugyanakkor tévedés lenne Szíriát a nyugati szakirodalomból ismert bukott államként definiálni, hiszen az állami funkciók részben müködnek. Így a fentiekben említett állami vákuum fogalmának (state vacuum) használata célravezetőbbnek tünik.

2. A második területet a főként kurdok dominálta Szíriai Demokratikus Erők (Syrian Democratic Forces - a továbbiakban: SDF) ellenőrzik, és Észak-Szíria jelentős részére kiterjed, beleértve az Eufrátesz folyó nyugati és kelet partját is. Itt érdemes

Kнатів: $i . m$.

A kéziratot 2020 márciusában zártuk le.

Qais FAREs: The Syrian Constitution: Assad's Magic Wand, [online], 2014 05. 08. Forrás: Carnegie Middle East Center [2020.04.01.] 
megjegyezni, hogy miközben a szíriai kurdok előszeretettel áldozatként tüntetik fel magukat, mégis területi szemszögből a nyertesei (legalábbis eddig) a konfliktusnak. Olyan területek felett is szereztek szuverenitást, amelyeket nem kurdok laknak többségben. Miközben a nyugati közvélemény a kurd kérdést gyakran normatív szempontból közelíti, aközben számos tanulmány objektív módon elemezte a PYD és az YPG által elkövetett atrocitásokat. A 2019 októberében bejelentett amerikai visszavonulás azonban alapvetően érinti az SDF és ezen belül pedig a kurd Népvédelmi Erők (YPG, Yekîneyên Parastina Gel) szíriai pozícióját.

3. A harmadik területet az úgynevezett Aszad-ellenes felkelők ellenőrzik Idlib városában és környékén. Miután a nemzetközi közösség felhagyott a felkelők támogatásával, így az Aszad-rezsim Oroszország segítségével, 2018 júliusára fokozatosan visszafoglalta a korábbiakban a felkelők által ellenőrzött területeket délen. A felkelők által ellenőrzött területen Szíria jelenlegi lakosságának mintegy 20\%-a, 3-3,5 millió fó él, amely Szíria összterületének mindössze 3\%-át teszi ki. ${ }^{8}$ Jelen sorok írásakor az Aszad-rezsim katonai hadműveleteket indított a felkelők bázisainak felszámolására, ami jelentősen megnöveli a belső menekültek (Internally Displaced Persons, IDP) számát Szírián belül. Az Egyesült Államok korábban elköteleződött a Szabad Szíriai Hadsereg (Free Syrian Army, FSA) mint az Aszad-ellenes felkelést koordináló szervezet támogatásában, azonban a Trump-adminisztráció alatt mindez leállt. Az Idlib környéki felkelést ma kevésbé a nyugati államok szövetségesének számító FSA, inkább a szalafista-dzsihádista szervezetek irányítják. Ezek közül is az al-Káidához köthető Hajat Tahrír as-Sám (Levante Felszabadítási Szervezete, HTS) nevü szervezet emelhető ki, amely jelenleg a térségben a domináns felkelöszervezet. A HTS elsősorban szíriai harcosokra támaszkodik, és a dzsihádot nem globálisan értelmezi, hanem „szírianizálja”. A HTS kifejezetten szoros kapcsolatokat ápol Törökországgal. ${ }^{9}$

4. Szírián belül a negyedik területi egységet az ország északi-nyugati, valamint északi középső területein Törökország ellenőrzi. Törökország szíriai katonai beavatkozása 2016 augusztusában kezdődött, és ezidáig három szakaszát különböztethetjük meg. 2016 augusztusában az Eufrátesz Pajzs hadmüvelet keretében Ankara az Eufrátesz folyótól nyugatra eső területek Iszlám Államtól, valamint a kurd csapatoktól (YPG) való megtisztítását valósította meg. A második török offenzívára (Olajághadmüvelet) 2018-ban került sor Afrín tartományban, amelynek célja Szíria északnyugati területeinek a kurd többségü SDF-erőktől való „megtisztítása” volt. A török katonai beavatkozás harmadik fázisa 2019 októberében történt, célja egy észak-szíriai biztonsági sáv kialakítása volt a török határ mentén. A török beavatkozás főbb motivációi kapcsán a következő szempontokat említhetjük: Szíria föderális államszerkezete kialakulásának megakadályozása, az Iszlám Államtól elfoglalt kurd területek megosztása, a menekültek visszatelepítése Észak-Szíriába, illetve az Aszadrezsim meggyengítése.

Charles Lister: Idlib’s Fate Defines Syria’s Future, [online], 2020. 01. 04. Forrás: Asharq Al-Awsat [2020. 04. 01.]

Sultan al KANJ: HTS Tries to 'Syrianize', [online] 2019. 08. Forrás: Chatham House [2020. 04. 01.] 
A szíriai konfliktus napjainkig mintegy félmillió halálos áldozattal, kétmillió sérülttel, megközelítőleg hét-nyolc milliós menekülthullámmal, és felbecsülhetetlen anyagi pusztítással járt. A 2019-2020 fordulójának eseményei mintegy egymillió fővel megnövelték a belső menekültek amúgy is felbecsülhetetlen számát. A szíriai polgárháború rendezésére a nemzetközi közösség számos kísérletet tett. A jelenlegi helyzet megértéséhez a következő részben a tanulmány röviden összefoglalja a legfontosabb ismereteket.

\section{A nemzetközi közösség törekvései a szíriai konfliktus politikai rendezésére: a genfi és az asztanai folyamat}

A nemzetközi közösség multilaterális erőfeszítései közül hármat érdemes megemlíteni: az Arab Liga törekvéseit, illetve a genfi és az asztanai folyamatot.

2010 decemberében a közismert tunéziai eseményekkel kezdetét vette a tüntetéshullám, közkeletü nevén az arab tavasz. Az arab államok alapvetően abban voltak érdekeltek, hogy a külső hatalmak intervencióját megelözve, maguk oldják meg a felmerült problémákat. Az Arab Államok Ligája (a továbbiakban: AL) éppen emiatt 2011 elején meghatározó szerepet próbált meg betölteni a válságkezelésben. Az Arab Liga mint regionális szervezet számára nagy dilemma volt, hogy szakítson-e a korábban a non-intervenció elvére épülő politikájával. Azonban látva az események eszkalálódását megkísérelte alakítani azok kimenetelét. Az Arab Liga mint szervezet bizonyos tagállamoknak a befolyása alá került, így mindenekelőtt Katar és Szaúd-Arábia fejtett ki érdemi aktivitást a kérdésben. A két állam furcsa módon kettős mércét alkalmazott a megmozdulásokkal kapcsolatban, míg Szíria vonatkozásában valódi politikai reformokat sürgetett, addig a Perzsa-öböl kapcsán - különösen Bahreinben - a felkelések féken tartásában, a tüntetések vérbe fojtásában volt érdekelt.

Az Arab Liga a tunéziai és egyiptomi tüntetések kapcsán inkább közvetítő szerepet töltött be az ellenzék és a rezsim között, de valójában meglehetösen inaktívnak bizonyult. Ezzel szemben a líbiai eset aktívabb szerepvállalásra késztette a szervezetet, amelynek célja az volt, hogy maga alakíthassa a konfliktust. Az Arab Liga felfüggesztette Líbia tagságát, azonban a későbbiekben az ENSZ égisze alatt született biztonsági tanácsi határozatok a NATO beavatkozását készítették elő. Az ENSZ Biztonsági Tanácsának aktív szerepvállalása paradox módon háttérbe szorította az Arab Ligát. Éppen ebből tanulva a szíriai tüntetések kirobbanásakor az AL célja a külső beavatkozás elkerülése volt, vagyis megpróbálta a reformok irányába terelni az eseményeket 2011 tavaszán és nyarán. ${ }^{10} 2011$ júliusában Nabíl al-Arabí (Nabil Elaraby), a szervezet újonnan kinevezett főtitkára és Aszad elnök találkozóján a tárgyalásos megoldást, politikai reformok bevezetését szorgalmazták. Az események azonban hamarosan más irányt vettek, az AL 2011 novemberében felfüggesztette Szíria tagságát Jemen és Libanon nem szavazata és Irak tartózkodása mellett. Az Arab Liga emellett szankciók bevezetésével próbálta az Aszad-rezsimet reformokra kényszeríteni. Katar 2011-ben és 2012-ben az Arab Liga elnökségi pozícióját gyakorolta rotációs alapon,

10 Zeynep Şahin Mencütek: The „Rebirth” of a Dead Organization?: Questioning the Role of the Arab League in the „Arab Uprisings” Process, Perceptions, 19. évf., 2014/2, 8. o. 
amely nagyobb súlyt biztosított a kisállam számára a szíriai kérdésben. ${ }^{11} \mathrm{Az}$ Arab Liga 2011 decemberében egy megfigyelőcsoport küldéséről döntött Szíriába, amelyben 166 fő foglalta el helyét. A megfigyelőcsoport célja kettős volt: egyrészt megakadályozni bármilyen külső beavatkozást az arab belügyekbe, másrészt megállítani a rezsim által a civil tüntetőkkel szemben alkalmazott erőszakot. ${ }^{12} \mathrm{Az}$ Arab Liga részletes javaslatot, béketervet fogalmazott meg elsősorban a véres konfliktus megelőzésére. 2012 januárjában az Arab Liga második javaslata Aszad távozásával kapcsolatos, a szervezet azt a javaslatot tette, hogy az elnök adja át helyettesének a hatalmat. A damaszkuszi vezetés azonban elutasította ezt a javaslatot, így az Arab Liga átadta az ügyet az ENSZ Biztonsági Tanácsának. ${ }^{13}$ Ezzel az Arab Liga kezéből kicsúsztak az események, az erőszak eszkalálódásának következtében januárban véget ért a megfigyelö misszió.

$\mathrm{Az}$ arab tavasz eseményeivel kapcsolatosan számos várakozás fogalmazódott meg az arab elit körében is. Ezen várakozások az arab világ újjáéledésével, egy új arab reneszánsszal kapcsolatosak. Valójában a szíriai konfliktus leképezi az arab világ megosztottságát, amelyet az Arab Ligának a válsággal kapcsolatos tehetetlensége is mutatott. ${ }^{14} \mathrm{~A}$ szíriai konfliktus keretében többféle törésvonal is megjelenik: egyrészt a globális hatalmak közötti ellentét (Egyesült Âllamok, Oroszország), másrészt pedig a regionális hidegháború (SzaúdArábia versus Irán, illetve későbbiekben a szaúdi-katari diplomáciai szakítás) manifesztálódott. 2011-2012 fordulóján a szíriai kérdés az ENSZ Biztonsági Tanácsa elé is került, ahol elsősorban egy orosz és egy kínai vétó akadályozta meg februárban egy, az Aszad-rezsimet elítélő határozat elfogadását. Oroszország és Kína éppen a líbiai beavatkozás következtében nem támogatta az elítélő határozat elfogadását, hiszen a két állam úgy látta, hogy ez könynyen egy külső katonai beavatkozást készíthet elö. Éppen emiatt kelt életre Nicolas Sarkozy francia elnök javaslata, a Szíria Barátai (Friends of Syria) nemzetközi összekötőcsoport, amely 2012-ben négy alkalommal is találkozott. A csoportnak föként olyan nyugati és nem nyugati államok a tagjai, amelyek az erőszak megfékezését, valamint Aszad távozását szeretnék elérni. E helyütt nincs lehetőségünk kitérni arra a számtalan politikai javaslatra, amelyet az egyes államok bilaterális alapon tettek, a tanulmány pusztán azokat a vitákat kívánja röviden érinteni, amelyek multilaterális keretek között zajlottak. Törökország például már 2011-ben kísérletet tett arra, hogy irányítása alatt összeszervezze az Aszadellenes ellenzéket. 2011 júliusától e törekvések felgyorsultak, ugyanis a kezdeti tüntetések a Damaszkuszban elkövetett merényletsorozatok következtében polgárháborúvá fajultak, és komoly emberi áldozatokkal jártak.

Az ENSZ égisze alatt indult útjára az úgynevezett genfi folyamat, amely hivatalosan minden érintett felet bevont a politikai egyeztetésbe. 2012. június 30-án megszületett a genfi folyamat első mérföldkövének tekintett közös nyilatkozat, amely egy hatpontos követelés megvalósítását tüzte ki elöírásként az Aszad-rezsim felé. Emellett a legfontosabb szempontként a politikai átmenet irányába tett lépéseket tartja. Ennek részeként egy átmeneti

11 Kristian Coates Ulrichsen: Qatar and the Arab Spring. Policy Drivers and Regional Implications, [online] 2014. 09. 13. o. Forrás: Carnegie Endowment [2020. 04. 01.]

12 MencüteK: $i$. m., 99.

13 Geneva Conference II: Challenges Faced in Syria and the Region, [online], Arab Center for Research and Policy Studies, Doha, 2014.

14 ZISSER: i. m., 5. 
kormányzótestület felállítását javasolja, amelynek tagjai között az ellenzék, illetve az Aszadrezsim tagjai is részt vehetnek. A közös nyilatkozat hangsúlyozza a lakosság bevonásán alapuló nemzeti párbeszéd indításának szükségességét, amelynek eredményeként egy új alkotmányos rend születne az államban. Az új alkotmányt népszavazással kell jóváhagyni, majd ezt követően szabad választásokat tartani. Az első genfi nyilatkozat hivatalosan a nagyhatalmak egyetértésével is találkozott, azonban éppen ezen a ponton fogalmazódtak meg azok a részletek, amelyek a szíriai kérdés rendezésének az alapkérdései. Ezek a problémahalmazok a következőkben definiálhatók:

- Mi legyen személy szerint Aszad elnök és közvetlen hozzátartozóinak a sorsa? Részt vehetnek-e bármilyen formában az átmenetben? A Baász párt jövője?

- Ki számít legitim ellenzéki szereplőnek Szíriában, és ki számít terroristának?

- Az új alkotmányban (ha ilyen lesz) hogyan szabályozzák a többség és a kisebbség viszonyát (föderalizmus versus unitárius állam kérdése)?

A 2012-es genfi nyilatkozat megfogalmazásában maga a szíriai rezsim nem ve(hete)tt részt. A szíriai szereplök pedig rendkívül megosztottak voltak a genfi folyamat elfogadásával kapcsolatban. ${ }^{15}$ A Szíriai Nemzeti Tanács, amely 2011 augusztusában Törökország támogatásával jött létre, ellenezte, hogy Aszadnak és családtagjainak bármilyen szerepe lehessen az átmenetben. A 2012 novemberében Katarban létrejött ellenzéki ernyőszervezet, a Szíriai Forradalmi és Ellenzéki Erők Nemzeti Koalíciója (röviden a Nemzeti Koalíció), amelynek a Szíriai Nemzeti Tanács is a tagja, elfogadta a genfi alapelveket. A rezsim számára pedig kitűnő alkalom volt, hogy az ellenzék bizonyos, számára nemkívánatos csoportjait terroristának bélyegezze.

A 2012-es első genfi nyilatkozat implementálása kapcsán nem sok lépés történt, ugyanis a fenti kérdések vonatkozásában - ki képviseli az ellenzéket, illetve a rezsim sorsa - nem volt egyetértés. A nemzetközi közösség nagy jelentőséget tulajdonított a genfi folyamat második felvonásának, amely 2014 januárjában kezdődött Montreaux-ben, és több ülés keretében folytatódott. Ennek a találkozónak az elsődleges kérdése az volt, hogy ki vegyen részt az ellenzék oldaláról a folyamatban. A Szíriai Nemzeti Tanács a kezdettől fogva ellenezte a részvétel bármilyen formáját, ugyanis azt az Aszad-rezsim legitimizálásával tette egyenértékűvé. A Nemzeti Koalíció azonban elfogadta a meghívást. A nemzetközi közösség a mérsékeltnek számító ellenzéki csoportokat szerette volna bevonni, így - többek között - a mérsékeltnek számító iszlámista szervezeteket is. A szíriai rezsim azonban feltétel nélkül elfogadta részvételét a tárgyalásokon. Az Iszlám Állam fenyegetést tett közzé azon csoportokkal és személyekkel szemben, akik részt vesznek a genfi tárgyalásokon. ${ }^{16} \mathrm{~A}$ második genfi tárgyalássorozat éppen emiatt érdemi eredmények nélkül zárult. Az egyes szíriai mediációval kapcsolatos elemzések megállapítják, hogy a konfliktusban érintett szereplők nem voltak érdekeltek abban, hogy a tárgyalóasztalnál megállapodjanak, hiszen úgy ér-

\footnotetext{
15 Muriel Asseburg - Heiko Wimmen: Geneva II - A Chance to Contain the Syrian Civil War [online], SWP Comments 10, January 2014, 3. o. Forrás: Stiftung Wissenschaft und Politik [2020. 04. 01.]

16 Geneva Conference II: Challenges Faced in Syria and the Region, i. m., 6.
} 
zékelték, hogy katonai úton érvényt szerezhetnek érdekeiknek. ${ }^{17}$ A genfi folyamat harmadik fázisa Staffan de Mistura különmegbízott közvetítési kísérletének égisze alatt zajlott. A szíriai ellenzéket a szaúdiak által támogatott, 34 tagot számláló ernyőszervezet, a High Negotiations Council képviselte. Végső soron a harmadik genfi kísérlet hamar megbukott 2016 februárjában.

Az egyes regionális és külső szereplők álláspontja a fenti kérdéssel kapcsolatosan a válság tíz esztendeje alatt dinamikusan változott. Az Egyesült Államok kezdetben - különösen az Obama-adminisztráció éveiben - hangoztatta, hogy az átmenet során Bassár alAszadnak távoznia kell a hatalomból. A 2013. augusztusi - a rezsim által vegyi fegyverekkel elkövetett - gútai támadást követően az Obama-adminisztráció katonai beavatkozással is fenyegetőzött. Oroszország ezzel szemben annak a narratívának adott hangot, hogy a közel-keleti állam legitim irányítója az Aszad-rezsim. Mint ismeretes, a 2014-ben elfogadott alkotmánymódosítás következtében az elnök személye egyszer újraválasztható. Miután 2014-ben Bassár al-Aszadot hét évre elnökké választották, így a következő elnökválasztásra 2021-ben kerülhet sor.

Ahogy egy tanulmány rámutat, nem is önmagában a globális és regionális szereplök álláspontja az érdekes, hanem az, hogy mennyire tartják fontosnak a szíriai kérdést. Ebben a szerepben pedig egyértelmüen Oroszország jelentőségét emelhetjük ki, amely a 2015-ös katonai beavatkozást követően még inkább meghatározza a szíriai események alakulását. Eközben az Egyesült Államok Közel-Kelet-politikájában - a Trump-adminisztráció éveiben - Szíria az Iszlám Állam katonai legyőzésén túlmenően nem stratégiai jelentőségü. ${ }^{18}$ Ehelyütt a terjedelmi korlátok miatt nincs lehetőségünk a szíriai konfliktus dinamikájának kifejtésére, azonban azt fontosnak tartottuk megállapítani, hogy Oroszország pozíciói erősebbek lettek a korábbiakhoz képest.

2017. január 23-án Oroszország kezdeményezésére - Irán és Törökország bevonásával - útjának indult az úgynevezett asztanai folyamat, amelynek elsődleges célja inkább egy tüzszünet életre hívása volt, semmint egy hosszabb távú - a genfi folyamatra épülö - béketerv kidolgozása. Az asztanai folyamat fontos előzménye volt Oroszország közvetlen katonai beavatkozása 2015-ben, amelynek célja egyrészt a terrorizmussal szembeni fellépés, másrészt pedig Moszkva politikai céljainak kiaknázása. Oroszország a 2015 decemberében elfogadott, 2254-es számú ENSZ Biztonsági Tanácsi határozatra hivatkozott, amely a feleket tüzszünetre és egy tárgyalásos 18 hónapos politikai átmenet indítására szólította fel. 2016 decemberében szimbolikus katonai eseményre került sor: az Aszad-rezsim visszafoglalta a stratégiai fontosságú Aleppó városát. ${ }^{19}$ Ez utóbbi kapcsán Moszkva éppen az asztanai folyamat keretében váltotta be politikai céljait, azaz, hogy a saját érdekeinek megfelelően irányítsa a szíriai átalakulást. Az asztanai folyamat valójában a konfliktus katonai szereplői találkozójának tekinthető, szemben a genfi folyamattal, amely pedig inkább a politikai

17 A béketervek részletes áttekintéséhez lásd: Magnus LundGren: Mediation in Syria: Initiatives, strategies, and obstacles, 2011-2016, Contemporary Security Policy, 37. évf., 2016/2, 273-288 o. Továbbá: Raymond HinnebUSCH et al.: UN Mediation in the Syrian Crisis: From Kofi Annan to Lakhdar Brahimi, [online], New York, 2016. 03. Forrás: International Peace Institute [2020. 04. 01.]

18 Erwin Van Veen: The Geopolitics of Syria’s Reconstruction: A Case of Matryoshka, Syria Studies, 11. évf., 2019/1, 33-56. o.

19 UN SC Resolution 2254, [online], 2015. 12. 18. Forrás: United Nations [2020. 04. 01.] 
aktorok tanácskozásával kapcsolatos. Az asztanai folyamat inkább a regionális szereplöket szólítja meg, míg a genfi folyamat inkább a globális szereplőket mozgósította. Az asztanai tárgyalások során Oroszország egy alkotmánytervezetet is megfogalmazott, amelyben olyan kérdések is napirendre kerültek, mint a kurd terület kérdése. ${ }^{20} \mathrm{~A}$ kurd kérdés kapcsán a dokumentum a „kulturális jogok” kérdését említette, amelynek tartalmát a későbbiekben pontosan meg kell határozni. A tervezet olyan kérdéseket is nyitva hagyott, mint például Szíria föderális alapon való átszervezésének lehetősége. Nem véletlen, hogy a szíriai szereplők - beleértve az ellenzéket is - negatívan álltak a megköröztetett orosz javaslathoz.

Kérdéses, hogy az asztanai folyamat a genfi folyamat folytatásaként, avagy egy attól teljesen eltérő politikai folyamatként értelmezhető. Oroszország az ENSZ Biztonsági Tanácsának 2254-es határozatát alapul véve 2017-ben négy deeszkalációs övezetet hozott létre Nyugat-Szíriában: Idlib tartomány, Észak-Homsz és környéke, Damaszkusz külvárosa (Gúta), illetve Dél-Szíria területe. A négy tartományban azonnali tüzszünet bevezetését követelte meg a felektől, és ennek ellenőrzését a három külső szereplő együttmüködésére - Oroszországra, Törökországra és Iránra - bízta. ${ }^{21}$ Az Aszad-rezsim nem hivatalos kommunikációjában a deeszkalációs zónák támogatását fejezte ki, azonban az ellenzéki szereplők külön-külön ellenezték annak tartalmát. A deeszkalációs zónák létesítése kapcsán Oroszország az ENSZ Biztonsági Tanácsának említett 2254-es határozatára is utalt, amikor jelezte, hogy az Iszlám Állammal és a Nuszra Fronttal szemben tovább kell folytatni a harcot. Ennek szellemében az Aszad-rezsim Moszkva támogatását élvezve, a terroristák elleni küzdelem jegyében Idlib kivételével a három deeszkalációs övezetet visszafoglalta, amely megalapozza azt a bevezetö kijelentést, hogy az Idlib ellen indított offenzíva a szíriai konfliktus újabb fejezetét hozta el. ${ }^{22}$

\section{Az Idlib elleni offenzíva jelentősége}

2019 decemberében az Aszad-rezsim Moszkva és szövetségesei (a libanoni Hezbolláh, illetve Irán és a síita milíciák) támogatásával offenzívát indított az Aszad-ellenes felkelők utolsó támaszát jelentő Idlib tartomány visszafoglalására. Ennek jelentősége a szíriai polgárháború szemszögéből, hogy az Iszlám Állam által ellenőrzött utolsó terület (az iraki-szíriai határ mentén található Bágúz) elfoglalásával, Idlib tartomány maradt az utolsó folt a térképen. A tágabb Idlib tartomány lakossága megközelítőleg 3 millió fö, amelyből mintegy 500 ezer-1 millió föt az ország más pontjairól telepítettek át (Internally displaced persons, IDPs). Az egyes Aszad-rezsim által visszafoglalt területekről gyakran buszokkal szállították a tartományba az ellenállókat. A korábbiakban említett asztanai megállapodás értelmében, 2017 májusában Oroszország, Irán és Törökország létrehozta a tágabb Idlib körzet deeszkalációs övezetét, amely határainak kijelölésére az év második felében került sor. 2018 szeptemberében Erdoğan és Putyin Szocsiban megállapodott egy 15 és 20 kilo-

20 Russian Draft Proposal for a New Syrian Constitution, [online], 2017. 02. 09. Forrás: Middle East Media Research Institute [2020.04.01.]

21 Jennifer CAfarella - Jason Zhou: Russia's Dead-end Diplomacy in Syria, [online], Washington, Institute for the Study of War, 2019. 11. 18. o. Forrás: Understanding War [2020. 04. 01.]

22 The Best of Bad Options for Syria’s Idlib, [online], Middle East Report No. 197, 2019. 03. 14. 3. o. Forrás: International Crisis Group [2020. 04. 01.] 
méter széles demilitarizált övezet létrehozásáról a deeszkalációs zónán belül, amelynek felügyeletét a két állam látja el. ${ }^{23}$

Politikai és katonai szempontból az idlibi deeszkalációs övezetben különféle csoportok müködnek. A térséget a Hajat Tahrír as-Sám (HTS) nevü radikális iszlámista szervezet dominálja, amely 2017-ben jött létre a Dzsabhat Fath as-Sám (korábban Nuszra Front) és szövetségeseinek összeolvadásával. A HTS egy dzsihádista-szalafista szervezet, amely az Iszlám Állammal szemben nagyrészt szíriai állampolgárokra építette a bázisát, de a szövetségesek között találunk ujgur és csecsen harcosokat is. A HTS oldalán harcoló külföldi harcosok száma a mai napig igen jelentős, egy forrás 6000 före teszi. ${ }^{24}$ A HTS az al-Káidához köthető radikális szervezet, amely egyben politikai célokat is megfogalmaz. 2016-ban, amikor a Nuszra Front megváltoztatta nevét Dzsabhat Fath as-Sámra, az átnevezés fontos eleme volt, hogy a szervezetre jellemző külső befolyást megszüntesse, ami elméletileg az al-Káidával való hivatalos szakítást is jelentette. ${ }^{25}$ A gyakorlatban azonban a korábban kialakult kapcsolatrendszert továbbra is fenntartotta a globális dzsihádista szervezettel.

2017 végén a HTS megalapította a Szíriai Megmentés Kormányát, amellyel egyben politikai szereplőként is definiálta magát. Abú Muhammed al-Dzsúláni, a HTS vezetője számos alkalommal a szervezet mérséklődéséről beszélt, ezzel a terrorista vádakkal szemben próbál meg fellépni. Dzsúláni egy 2020. januári - az International Crisis Groupnak adott - interjújában a HTS korábban elkövetett hibáiról beszélt, és a többi ellenzéki csoporttal kapcsolatban pragmatikus hozzáállást kíván tanúsítani. Az interjú kapcsán a legföbb kérdés az volt, hogy mennyiben tekinthető taktikai játszmának az Idlibben körülzárt szervezet részéről a mérséklődés, másrészt mennyiben hihető, hogy a HTS nem rendelkezik külső kapcsolatokkal. Annál is inkább, hiszen a HTS együttmüködik - többek között - az al-Káida helyi szervezetének tartott Hurrász ad-Dín (A Vallás Örzői) nevü szervezettel. ${ }^{26}$ Dzsúláni retorikájában a helyi problémákra adott politikai válaszok jelennek meg, és beszédeiből kikopott a dzsihádista szóhasználat. Miközben a HTS-t hivatalosan az Egyesült Államok és Oroszország is terrorszervezetként tartja nyilván, addig Törökország paradox módon pragmatikusan együttmüködik a radikális iszlámista szervezettel. A HTS a Törökországgal folytatott gazdasági kapcsolatok monopóliuma fölött is rendelkezik Idlibben, ami nem mellékes a Szíriai Megmentés Kormányának politikai céljai szempontjából sem.

A HTS mellett más transznacionális kapcsolatrendszerrel bíró dzsihádista szervezetek is müködnek Idlibben, amelyeket a nagyhatalmak a HTS-nél is veszélyesebbnek tartanak biztonsági szempontból. A korábbiakban említett Hurrász ad-Dín kimondottan az al-Káida helyi szervezetének tekinthető, amely a Nuszra Frontból vált ki. A Turkesztáni Iszlám Párt főként külföldi ujgur harcosokból szerveződik, és Szíriában az Aszad-rezsim ellen harcol. ${ }^{27}$

Az Aszad-ellenes felkelők nem dzsihádista szárnyát számos szervezet képviseli. Ezek közül egy ernyőszervezet, a Nemzeti Felszabadítási Front a meghatározó, ugyanakkor

23 The Best of Bad Options for Syria’s Idlib, i. m., 3-4.

24 KANJ: $i . m$.

25 Aymenn Jawad Al-Tamimi: Idlib and Its Environs. Narrowing Prospects for a Rebel Holdout, [online], Policy Notes, PN75, 2020, 02. 3. o. Forrás: The Washington Institute for Near East Policy [2020. 04. 01.]

26 The Jihadist Factor in Syria’s Idlib: A Conversation with Abu Mohammed al-Jolani, [online], 2020. 02. 20. Forrás: International Crisis Group [2020. 04. 01.]

27 The Best of Bad Options for Syria's Idlib: i. m., 17-20. 
a HTS-hez képest katonai és politikai súlyát tekintve csak másodlagosnak tekinthető. A front tagjai között találjuk például a Törökország feltétlen támogatását élvező Fajlak asSám (Szíriai Légió) vagy az Ahrár as-Sám (Szíria felszabadítói) nevű szervezetet.

2017 szeptemberében a felkelők Idlib tartományban $9000 \mathrm{~km}^{2}$ területet ellenőriztek, amely az Aszad-rezsim sorozatos lépései következtében fokozatosan lecsökkent. ${ }^{28}$ Oroszország az elmúlt években meglehetősen neheztelt az Idlib tartományt ellenőrzés alatt tartó HTS-re, így többek között ezzel is magyarázható, hogy zöld utat adott az Aszadrezsimnek a katonai beavatkozásra. Moszkvának - többek között - nem tetszett, hogy a pragmatikusnak tünő HTS szoros együttmüködést folytat olyan dzsihádista csoportokkal, amelyeknek csecsen tagjai is vannak. Továbbá a Hmejmím orosz ellenőrzés alatt álló légi támaszpontot folyamatos katonai támadás érte a HTS és szövetségesei részéről, illetve az idlibi csoportok folyamatos fegyveres harcban álltak az Aszad-rezsim erőivel is. Oroszország ráadásul Törökországra is neheztelt, hogy együttmüködik a HTS-sel, illetve nem lép fel kellőképpen a dzsihádista szervezetekkel szemben, hiszen 2019 tavaszától Törökország részt vállalt az idlibi demilitarizált övezet járőrözésében, illetve a korábbi megállapodások értelmében megfigyelöposztokat hozott létre a tartományban.

Mielött az Idlib elleni offenzíva elindult, 2019 szeptemberében létrejött az ENSZ égisze alatt a Szíriai Alkotmányozó Bizottság, amely meg is tartotta első ülését Genfben. A testület megalapításában Oroszország óriási szerepet játszott, amely nem első ízben kísérelte meg a szemben álló szíriai feleket egy asztalhoz ültetni. A Moszkva támogatását élvező Aszad-rezsim katonai sikerei nagymértékben magyarázzák a 2019 őszi időzítést, hiszen egy, a politikai rendezésről szóló tárgyalássorozat keretében a katonai színtéren jelentkező előnyöket át lehet váltani. Mint korábban már utaltunk rá, Moszkva már az asztanai folyamat legelején megfogalmazott alkotmányos alapelveket amolyan kísérletként, hogy mit szólnak hozzá a szíriai felek. Bár Oroszország érdeke jelenleg az Aszad-rezsim fennmaradásához füződik, ez nem jelenti azt, hogy Moszkva mindenáron ragaszkodna akár Bassár al-Aszad személyéhez, akár az eddigi rendszerhez. Moszkva számára a hatalommegosztás bármilyen formája teljes mértékben elképzelhető, miként az ország föderális alapon való átszervezése is. Miután az Egyesült Államok érdemben nem szól bele a szíriai belpolitikai folyamatokba, így Oroszországnak valójában fel van adva a lecke, hogy maga közvetítsen a szíriai felek között, illetve, ami nem kis kihívást jelent, hogy egyensúlyozzon a regionális szereplők között (lásd később).

Az Alkotmányozó Bizottság egy háromszor 50 fös testület. Az Aszad-rezsim delegációja 50 föt alkot. A második egységet az úgynevezett politikai ellenzék képezi, a Szíriai Tárgyaló Bizottság, amelynek 50 tagját a szíriai politikai ellenzéket képviselő Felső Tárgyaló Bizottság (High Negotiations Committee) nevezi ki. A tanulmány korábban említette, hogy a bizottság 2016-ban szaúdi kezdeményezésre jött létre, hogy a genfi tárgyalások újabb fordulója előtt legitim ellenzéke jöhessen létre az Aszad-rezsimnek. Összetételében így értelemszerüen föként a mérsékelt szunnita arab országok Aszad-ellenes nézetei érvényesülnek. A szervezet a politikai ellenzék (Nemzeti Koalíció) mellett katonai szervezeteket is tagjai között tudhat (például az Idlibben jelen lévő, korábban említett Ahrár as-Sám). A harmadik 50 főt a szí-

28 Fabrice Balanche: Idlib May Become the Next Gaza Strip, Policy Watch 3288, 2020. 03. 26. Forrás: The Washington Institute for Near East Policy [2020. 04. 01.] 
riai civil társadalom tagjai közül az ENSZ nevezte ki. ${ }^{29} \mathrm{Az}$ ENSZ szíriai különmegbízottja, Geir O. Pedersen hozta tető alá a tárgyalások első fordulóját, amelyre a képviselők többsége Oroszország által bérelt különrepülőgépen érkezett. Ezzel a gesztussal Moszkva megpróbált az általa irányított folyamatnak a genfi folyamat égisze alatt nemzetközi legitimációt biztosítani. A 2019 végén megtartott ülések témája volt - többek között - a kurd közösség esetleges jogainak kérdése (föderalizmus kérdése), valamint az alkotmányozási folyamat kilátásai, amelyek természetesen nem váltottak ki konszenzust a résztvevőkből.

A 2019 decemberében a rezsim által Idlib tartomány visszafoglalására indított offenzíva jegelte az alkotmányozásról folyó tárgyalásokat. A katonai offenzíva néhány hete alatt a felkelők által ellenőrzött terület $9000 \mathrm{~km}^{2}$-ről 3000 km²-re szükült le, közel 50 ezer felkelő zsúfolódott össze egy szük területen. Egyes vélemények szerint Idlib tartomány a humanitárius problémák alapján a Gázai övezethez hasonlítható. ${ }^{30}$ Oroszország komoly kereszttűzbe került, miután szövetségese, Törökország hevesen ellenezte az Aszad-rezsim elörenyomulását. Ankara véleménye szerint ugyanis az Aszad-rezsim megsértette a korábbi megállapodásokat (Asztana és Szocsi), amelyeket Moszkva hallgatólagosan jóváhagyott. Ankara egyrészt meg kívánja védeni befolyását a HTS-en keresztül a térségben, illetve el akarja kerülni, hogy egy újabb milliós menekülthullám érje el a török államot. Így 2020. március 5-én Oroszország és Törökország tüzszüneti megállapodást kötött Idlib kapcsán, amely leállította a harcokat, és az Aszad-rezsimet is erre kötelezte. Kérdés, hogy a Szíriát is igen erőteljesen utolérő koronavírus-járvány mennyiben járul hozzá a fegyvernyugvás hosszabb ideig tartó fenntartásához.

A 2019-2020-as idlibi offenzíva eredményeként tehát a felkelők által ellenőrzött terület még kisebb lett. Ezen a ponton érdemes felvetni a szíriai újjáépítéssel kapcsolatos politikai, gazdasági és humanitárius kérdéseket.

\section{A szíriai újjáépítés politikai gazdaságtana}

Egyes vélemények szerint a szíriai újjáépítéshez mintegy 250 milliárd amerikai dollárra lenne szükség, amely számlát kérdéses, hogy a regionális és globális szereplők hogyan tudnak, illetve akarnak-e kiegyenlíteni. ${ }^{31}$ Ahogy a fentiekben láttuk, a geopolitikai versengés a szíriai konfliktusban nem ért véget, az egyes regionális és globális szereplőknek eltéró érdekeik és lehetőségeik vannak a szíriai újjáépítésben. A szíriai konfliktusban meghatározó geopolitikai szereplők - így Oroszország és Irán - gazdasági szempontból csekély lehetőségekkel rendelkezik a rekonstrukció pénzügyi támogatására. És megfordítva, a gazdaságilag meghatározó aktorok - így az Európai Unió, az Egyesült Államok és a GCC-államok - kisebb geopolitikai súllyal bírnak jelen pillanatban. ${ }^{32}$

Az Aszad-rezsim sajátos politikai-gazdasági rendszere - a tüntetések kezdetekor - 2011 márciusában a Baász Párt mellett, a fegyveres erőkre és a különféle egyéb milíciákra (például

\footnotetext{
29 Jomana QADDOUR: The constitutional committee must be part of a holistic Syrian Process, [online], 2019. 11. 26. Forrás: Middle East Institute [2020. 04. 01.]

30 BALANCHE: $i . m$.

31 VEEN: i. m., 34.

32 Raymond Hinnebusch: The Battle over Syria’s Reconstruction, Global Policy, 11. évf., 2020/1, 114. o.
} 
a rezsim irányítási alatt álló Sabíha milícia), valamint a szunnita középosztály támogatására épült. Az az íratlan társadalmi szerződés, amely a rezsim és a szíriai társadalom egyes rétegei között létezett, a polgárháború kirobbanásával értelemszerüen felbomlott ugyan, azonban számos kormányzati intézmény továbbra is folytonosságot mutat. Az Aszad-rezsim így a világ felé azt a narratívát próbálja meg eladni, hogy működőképes. Bassár al-Aszad álláspontja, hogy az országot elhagyó menekülteknek nem kell visszatérniük, hiszen, ahogy több interjújában kifejezte, egy „egészségesebb és homogénebb társadalom” jobban megfelelne Szíriának. ${ }^{33}$ Ezért az Aszad-rezsimnek kifejezetten kapóra jött, hogy a rezsimmel szemben álló ellenzékhez kötődő személyek elhagyták az országot. Mindez szektariánus szempontból is kedvez a rezsim túlélésének.

A polgárháború évei alatt két párhuzamosan müködő gazdasági rendszer épült ki Szíriában a maga sajátos játékszabályaival együtt. Egyrészt, a rezsim által ellenőrzött területeken a katonai milíciák, helyi hadvezérek és üzletemberek által müködtetett háborús gazdaság, amely a csempészetre, adóztatásra és rablógazdálkodásra épül. Négy jelentősebb hadvezér mellett 20-30 kisebb müködteti a szíriai gazdaságot, ${ }^{34}$ miközben a szíriai polgárháború kitermelte a rezsimhez hüséges üzletemberek egy újabb generációját, amely saját túlélését kívánja biztosítani az elnyomás és megfélemlítés bármilyen eszközével. A 2018 áprilisában közzétett 10. számú elnöki rendelet lehetővé tette az országot elhagyó állampolgárok ingatlanvagyonának elkobzását. Mivel a tulajdonosnak bizonyítania kell a helyi hatóságok felé, hogy állampolgárként birtokosa az adott ingatlannak, amit a többség a jelenlegi polgárháborús helyzetben nem tud megtenni, így ez lehetővé teszi a helyi rezsimhez lojális üzletemberek és hadvezérek „megjutalmazását” és mozgósítását az újjáépítésben. ${ }^{35}$ A 10. számú elnöki rendeletet az Európai Unió és az Egyesült Államok hevesen bírálta, ugyanakkor az illeszkedik abba az Aszad-féle stratégiába, hogy a menekültek visszatérése nélkül valósítsák meg az újjáépítést.

Steven Heydemann az autoritárius rendszer stabilizációjáról írt tanulmányában a fenti jelenség kapcsán azon álláspontjának ad hangot, hogy miközben Szíria törékeny állam, ettől még a felépített gazdasági modell akár működőképes is lehet az elkövetkezendő években. ${ }^{36} \mathrm{~A}$ müködőképes háborús gazdaság kiváló példája az olajbeszerzés és az energiatermelés példája. Az Aszad-rezsim, mint ismeretes, közvetítőkön keresztül szerzett be olajat az Iszlám Állam által ellenőrzött területekről, amelyek ma nagyrészt a PYD ellenőrzése alatt állnak. A visszatérő állami szolgáltatások azt a látszatot keltik, hogy az Aszad-rezsim fenntartható gazdaságilag és politikailag. Ugyanakkor meg kell említeni, hogy bármilyen külső gazdasági segítség egyrészt önmagában is fontos anyagi forrás a rezsim számára, másrészt politikai legitimációt jelent. Éppen ezért kérdéses, hogy az Európai Unió, amely több ízben szíriai donorkonferenciát is rendezett, illetve az Egyesült Államok mennyiben kíván egy olyan újjáépítést támogatni, amely nem a politikai érdekeinek megfelelően történik.

\footnotetext{
3 More Healthy and Harmonious Society, [online], 2017. 08. 20. Forrás: Syria Times [2020. 04. 01.]

34 Hinnebusch: $i$. m., 115.

35 Nadine Almanasfi: State-led urban development in Syria and the prospects for effective post-conflict reconstruction, Syria Studies, 11. évf., 2019/1, 88. o.

36 Steven Heydemann: Beyond Fragility: Syria and the Challenges of Reconstruction in Fierce States, [online], 2018. 06. Forrás: Foreign Policy at Brookings [2020. 04. 01.]
} 
A nyugati államok szerint ugyanis bárminemü gazdasági segítséget a politikai átmenethez szükséges kapcsolni (genfi folyamat elörehaladása).

Másrészt az ellenzék, illetve a felkelők által ellenőrzött területeken is létrejött egy párhuzamos gazdasági rendszer. Amint korábban láthattuk, hogy az Iszlám Állam is kiépítette a maga háborús gazdaságát, és ugyanez a helyzet Idlibben is, ahol a HTS Törökországgal mint patrónussal és közvetítő személyekkel építette ki a maga gazdasági hátországát. Ebben szerepet játszik a korábbiakban említett, a HTS által dominált Nemzeti Megmentés Kormánya is, amely nemcsak politikai, hanem gazdasági jellegü vállalkozás is. ${ }^{37}$ Nyilván, ha és amennyiben a rezsim Moszkva támogatásával felszámolja a felkelők által ellenőrzött területet, akkor a török befolyás alatt álló rész és az észak-szíriai Rodzsava autonóm tartomány kivételével valamennyi terület az Aszad-rezsim szuverenitása alá tartozik majd. Valójában ebből a szempontból a kulcsfontosságú Szíria nyugati tartományai, a Damaszkusz-Homsz-Hama-Aleppó-vonal feletti ellenőrzés, hiszen a lakosság nagy része itt összpontosul. Ez a terület pedig, Idlib tartományt leszámítva, visszakerült az Aszadrezsim ellenőrzése alá.

\section{A szíriai újjáépítés geopolitikája és geoökonómiája}

Valójában Szíria további sorsát nagymértékben meghatározzák az egyes regionális és globális hatalmak érdekütközései. Érdemes röviden összefoglalni az egyes aktorok jelenlegi álláspontját az újjáépítéssel kapcsolatban.

\section{Oroszország}

Jelen pillanatban egyértelmüen Oroszország a legfőbb alakítója a Szíriával kapcsolatos politikai és katonai folyamatoknak. Oroszország beavatkozása nem új keletű, azonban 2015-ben Moszkva katonai intervenciójával új szintre emelkedett. Oroszország megpróbál egyensúlyozni az Aszad-rezsim, az egyéb szíriai szereplők (kurdok) és a regionális aktorok (Irán, Izrael és Törökország) között. Miközben a regionális szereplök többnyire pusztán biztonsági aspektusból szemlélik a kérdést, addig Oroszország a komplexebb megoldásban érdekelt, de mindezt úgy, hogy anyagilag viszonylag keveset kelljen befektetni Szíriában, viszont annak magas legyen az anyagi és politikai megtérülése. Oroszország a szíriai válságon keresztül demonstrálni tudja a világnak, hogy meghatározó globális szereplő (power projection). Ezt bizonyítja, hogy Oroszország az elmúlt időszakban képes volt a saját érdekeinek megfelelően alakítani a politikai folyamatokat (Asztana, Szocsi és a legutóbbi alkotmányozással kapcsolatos egyeztetések), és a katonai események is Moszkva álláspontja szerint zajlottak. Oroszország gazdasági részvételével kapcsolatban a szíriai újjáépítésben azonban érdemes felidézni a Dél-Szíriában történt eseményeket. Mint ismeretes, a felkelők kiüzését követően Moszkva a déli tartomány gazdasági újjáépítésére és politikai megbékélésre tett ígéretet. 2018 júliusában a déli Boszra városában Moszkva egy megbékélési dokumentumot hozott tető alá, amelyhez a déli ellenzéki fegyveres csoportok is csatlakoztak. A megegyezés

37 The Best of Bad Options for Syria's Idlib: i. m., 10. 
értelmében a belső menekültek visszatelepítését, működő állami intézményeket és gazdasági lehetőségeket ígért. Mindenekelött Jordánia közelsége komoly lehetőségeket tartogatott valamennyi csoport számára. Valójában Irán és az Aszad-rezsim nem tartotta pozitívnak a „terroristának” bélyegzett felkelőkkel való bármilyen jellegü együttmüködést, és megkísérelték a gyakorlatban megakadályozni a megállapodás végrehajtását. Így Oroszországnak nem sikerült ígéreteit Dél-Szíria vonatkozásában betartani, Moszkva szerepvállalása egyedül a 2019-ben szembekerülő Irán és Izrael katonai szétválasztásában merült ki. ${ }^{38}$

Oroszország ebből kifolyólag abban érdekelt, hogy az asztanai és genfi folyamatokat tovább folytassa, és egy olyan korlátozott jellegü hatalommegosztást vezényeljen le, amelynek keretében az Aszad-rezsim ugyan fennmarad, viszont bizonyos ellenzéki csoportokat bevennének a hatalomba. Ez egyben azt is jelenti, hogy Moszkva az Aszad-rezsimre kliensként és nem egyenrangú partnerként tekint.

Gazdasági szempontból Oroszország 2008 óta mintegy 20 milliárd amerikai dollárt fektetett be Szíriában. ${ }^{39}$ Oroszország érdekelt abban, hogy a szíriai energiaipar keretében különféle koncessziókhoz jusson. 2019-ben az orosz Stroytransgaz nevü vállalat nyerte meg Tartúsz kikötő újjáépítésének projektjét mintegy 500 millió dollár értékben. Emellett orosz vállalatok tárgyalnak a szíriai vasútvonal fejlesztéséről. ${ }^{40}$ Miközben Oroszország és Törökország számos kérdésben érdekellentétbe került a szíriai események kapcsán (a rezsim offenzívája Idlib ellen), addig közös érdek vezérli a két államot a térség tágabb geopolitikai erőviszonyait illetően. Mint ismeretes Törökország és Oroszország kimaradt az EastMed, Kelet-Mediterráneum gázmezőprojektből, amelyben Izrael, Ciprus és Görögország aktivizálta magát.

\section{Az Egyesült Államok és az Európai Unió}

Az úgynevezett nyugati világ az ENSZ Biztonsági Tanácsának 2254-es számú határozata értelmében abban érdekelt, hogy úgy támogassa Szíria újjáépítését, hogy feltételként elösegítse a politikai átmenetet. Mind Washington, mind Brüsszel mintha szakított volna azon korábbi politikájával, amely az Aszad-rezsim megdöntését tüzte volna ki. Mindez azonban nem jelenti azt, hogy a nyugati világ támogatna egy olyan átmenetet, amely a fentiekben bemutatott módon az Aszad-rezsim megerősödéséhez és végső soron annak politikai legitimációjához vezetne. Az Egyesült Államok Szíria-politikája komplex megközelítésen alapul, amelynek alapelvei a következők: Irán marginalizálása, a terrorizmussal szembeni fellépés, az Aszad-rezsim elrettentése akár katonai eszközökkel is (lásd 2017-ben és 2018-ban több alkalommal légitámadás), és Izrael védelmének szavatolása. E célok érdekében az Egyesült Államok az Iszlám Állam elleni harc során is és ezt követően is korlátozottan együttműködött Oroszországgal Szíria területén. ${ }^{41}$ Washington azonban mindent el fog követni, hogy megakadályozza a rezsim politikai legitimálását, és mindenféle újjáépítési

\footnotetext{
Cafarella-Zhou: $i . m ., 23$.

Hinnebusch: $i$. m., 118.

40 Aron Lund: From Cold War to Civil War: 75 Years of Russian-Syrian Relations, [online], Swedish Institute of International Affairs, 2019/7, 44. o. Forrás: Swedish Institute of International Affairs [2020. 04. 01.]

${ }^{41}$ Michael A. Ratney: Five Conundrums: The United States and the Conflict in Syria, [online], Strategic Perspectives 32, 2019. 07. Forrás: Institute for National Strategic Studies [2020. 04. 01.]
} 
támogatást blokkolni fog, amely kapcsolatba hozható az Aszad-rezsimmel. ${ }^{42}$ Az Egyesült Államok számára egy másik fontos kérdés az amerikai-török kapcsolatok alakulása, illetve az orosz-török kapcsolatok mélyülése. Ez utóbbit Washington árgus szemekkel figyeli, és ennyiben az Idlib kapcsán jelentkező orosz-török feszültségek bizonyos értelemben az Egyesült Államok érdekeit szolgálták. A humanitárius szempontokat is figyelembe véve azonban az Idlib kapcsán kötött tüzszünet fontos lépés volt az amerikai külpolitika szempontjából.

Az Európai Unió csak részben azonosul az amerikai elképzelésekkel, amennyiben az ENSZ BT 2254-es határozatában lefektetett politikai átmenethez (kondicionalitás) köti a támogatás valamennyi formáját. Brüsszel és a tagállamok számára az egyik fő kérdés a Szíriából érkező esetleges újabb menekülthullám megelözése. ${ }^{43}$ Miközben Törökország és az EU érdekei jelentős mértékben távolodtak egymástól az Idlib kapcsán kialakult helyzetben, amelyet Ankara alkupozíciójának javítására használt fel, egyfajta egymásrautaltságot figyelhetünk meg.

\section{Irán}

Irán elsősorban a szíriai fegyveres erők közvetlen tanácsadásával, támogatásával fejezte ki az Aszad-rezsim iránti elköteleződését. Irán számára a szíriai konfliktus saját befolyási övezetének összekötését jelenti (az erőteljes iráni befolyás alatt álló libanoni Hezbolláh és Irak között Szíria jelenti a kapcsot). Szíriában elsődlegesen az Iszlám Forradalmi Gárda politikai és gazdasági érdekei jelentek meg, nem egy esetben a síita milíciákon keresztül (al-Hasd asSaabí, Népi Mobilizációs Erők). Irán gazdaságilag is érdekeltté vált a szíriai konfliktusban, amikor a Forradalmi Gárda Szíria telekommunikációs szektorában, az elektromos áram termelésében és a foszfátbányászatban szerzett részesedést az elmúlt esztendőkben. ${ }^{44}$ Irán lehetőségeit azonban az amerikai-iráni kapcsolatok fokozatos megromlása nagymértékben korlátozta. Szíriával szemben az Egyesült Államok egyre súlyosabb szankciókat foganatosított. A 2018-ban bevezetett újabb szankciók már azokat a külföldi vállalatokat is sújtották, amelyek az Aszad-rezsimmel kívántak gazdasági kapcsolatokat létesíteni. Az Irán ellen bevezetett újabb szankciók pedig még inkább nehezítik a helyzetet. ${ }^{45}$

Irán geopolitikai lehetőségei is korlátozottá váltak a Forradalmi Gárda parancsnokának, Kászim Szulejmáni 2020. januári meggyilkolását követően. Mint ismeretes ugyanebben az akcióban vesztette életét Abú Mahdi al-Muhandisz, aki a Katáib Hezbolláh iraki milícia vezetője, valamint a korábban említett Népi Mobilizációs Erők helyettese volt. Miután Irán befolyásában az úgynevezett síita hálózatnak meghatározó szerepe volt, így Teherán pozíciói kifejezetten gyengültek Szíriában. Az Idlib kapcsán zajló 2020 eleji offenzívában már a Népi Mobilizációs Erők helyett Irán régi szövetségese, a libanoni Hezbolláh vett részt Aszad oldalán. A koronavírus által is erőteljesen érintett Irán befolyását mintha Moszkva

42 Hinnebusch: i. m., 118.

43 Ways Out of Europe’s Syria Reconstruction Conundrum, [online], Middle East Report, No. 209. 2019. 11. 25. Forrás: International Crisis Group. [2020. 04. 01.]

44 Faysal Itani: Geo-economics: Russia and Iran in Syria. Syria Studies, 11. évf., 2019/1, 29. o.

45 Sinan Натанет: Russia and Iran: Economic Influence in Syria, [online], Research Paper, Middle East and North Africa Program, 2019. 03. 17. o. Forrás: Chatham House [2020. 04. 01.] 
is csökkenteni szeretné. Oroszország és Irán érdekei nagymértékben találkoznak a szíriai konfliktussal kapcsolatban, azonban nem minden iráni jelenlét és akció áll Moszkva érdekében. ${ }^{46}$

Az Öböl Menti Együttmüködési Tanács (GCC) államai közül az Egyesült Arab Emirátusok (UAE) szerepe emelhető ki a szíriai kérdés kapcsán, amennyiben az normalizálta viszonyát az Aszad-rezsimmel. Az UAE 2015-től kezdve fokozatosan hátat fordított a szíriai konfliktusnak, azonban 2018-ban újranyitotta damaszkuszi nagykövetségét. Az Emirátusok külpolitikájának hátterében Törökország és Irán ellensúlyozása állhat, illetve az újjáépítés során megnyíló gazdasági lehetőségek kiaknázása. ${ }^{47} \mathrm{~A}$ többi GCC-állam, úgy tűnik, csak akkor kívánja gazdasági eszközeit bevetni a szíriai újjáépítésben, ha és amennyiben Irán eltávolodik a szíriai eseményektől. A szíriai újjáépítés ebben az értelemben a közel-keleti új hidegháború az Irán vs. Szaúd-Arábia konfliktus foglyává is válik. ${ }^{48}$ Miközben a 2020. januári események, a szankciók, valamint a koronavírus Irán pozícióit érdemben rontották Szíriában is, aligha számíthatunk arra, hogy Teherán ne legyen résztvevője a további folyamatoknak a közel-keleti államban.

\section{Törökország}

Törökország a többi regionális szereplöhöz képest lényegesen nagyobb súllyal vehet részt a szíriai újjáépítésben, amennyiben az általa ellenőrzött északnyugati területeken az újjáépítést a helyi szervezeteken keresztül maga irányítja. Ankara további célja ezzel szemben a kurdok által ellenőrzött területek marginalizálása. ${ }^{49}$ Törökország jelenleg is gazdasági kapcsolatokat ápol a felkelők által ellenőrzött Idlib tartománnyal is, így bizonyos értelemben részt vállal a korábban említett háborús gazdaság fenntartásában. Törökország a török gazdasági és politikai célokat szem előtt tartva építi befolyási övezetét hosszú távra Észak-Szíriában. Ankara célja a befolyási övezetének építésével a szíriai menekültek fokozatos visszatelepítése, ami alapvető biztonsági problémákat jelenthet a későbbiekben a török-szíriai határ mentén. Továbbá a kurd területek elszigetelésére tett török kísérlet biztonsági problémákat generálhat hosszabb távon is a török újjáépítési célok szemszögéből. Törökország letett arról a kezdeti álláspontjáról, hogy mindenáron az Aszad-rezsim megbuktatásában lássa a szíriai konfliktus rendezésének megoldását. Ezzel egyidejüleg azonban Ankara abban sem érdekelt, hogy Moszkva és Damaszkusz érdekeinek megfelelő visszarendeződés történjen a közel-keleti országban. Kérdéses, hogy az Idlib kapcsán 2020. februárban és márciusban kialakult feszültségnek milyen következményei lesznek. Mint ismeretes a 2018-as orosz-török megállapodás értelmében a török katonák a török ellenőrzőpont logisztikai utánpótlását végezték, amikor - Ankara álláspontja szerint - szíriai

\footnotetext{
46 Anton Mardasov: Is COVID-19 changing Astana allies' dynamics in Syria?, [online], 2020. 03. 31. Forrás: Al-Monitor [2020. 04. 01.]

47 Joseph DAHER: Dynamics and Evolution of UAE-Syria Relations: Between Expectations and Obstacles, [online], Wartime and Post-conflict in Syria, Research Project Report, 2019/14, 2019. 10. 25. Forrás: Robert Schuman Center for Advanced Studies, European University Institute [2020. 04. 01.]

48 Hinnebusch: i. m., 119.

49 Jan van Leeuwen - Erwin van Veen: Turkey in northwestern Syria. Rebuilding empire at the margins, [online], $C R U$ Policy Brief, 2019. 06. Forrás: Clingendael [2020. 04. 01.]
} 
vadászgépek megtámadták. Az akcióban 34 török katona vesztette életét, és 70 fö megsebesült. Egyes források szerint nem az Aszad-rezsim gépei, hanem orosz gépek végeztek a török katonákkal. Mindenesetre a márciusi tűzszünet ideiglenesen jegelte a problémákat. ${ }^{50}$

\section{Konklúzió}

A 2020. március 5-ei orosz-török tüzszünet véget vetett az eszkalációnak, amelyet az Aszad-rezsim Moszkva támogatásával indított Idlib ellen. 2017 óta azonban az Aszadrezsim a felkelők által kontrollált területek döntő hányadát visszafoglalta, vagy Idlib esetén a terület nagyságát jelentős mértékben visszaszorította. A kurdok által dominált Szíriai Demokratikus Erők által ellenőrzött észak-szíriai területek, valamint a török ütközőterületek mellett Idlib a polgárháború utolsó katonai felvonásának tekinthető. Éppen emiatt a politikai rendezés kérdése, valamint a gazdasági újjáépítés a nemzetközi közösség napirendjére került. Az Aszad-rezsim túlélte a polgárháborút, és a nyugati világ valamennyi kísérlete ellenére nem sikerült megakadályozni, hogy egy úgynevezett „elvadult államot” (fierce state) építsen ki. ${ }^{51} \mathrm{Az}$ ilyen típusú államban az elit egyetlen célja a saját pozíciójának megmentése bármilyen erőszakos eszközzel. Az elit részben régi tagjai (Aszad elnök unokatestvére, Rámi Maklúf), részben az újonnan feltörekedett üzletemberek (az építőiparban tevékenykedő Kálid az-Zubájdi, a hotelszektorban érdekeltséggel rendelkező Nádir Kálej vagy Számir Foz) jelentős állami megrendelésekhez jutnak, és a helyi milíciákkal kiegészülve egy összességében müködőképes gazdasági és politikai rendszert építenek ki, amely függ a külső patrónusoktól, legfőképpen Oroszországtól és Irántól. Miután az Egyesült Államok hivatalosan is felfüggesztette az Aszad-rezsim megdöntését megcélzó felkelők katonai támogatását, így Moszkva és Teherán támogatásával Damaszkusz egyre jobb katonai helyzetbe került.

A regionális hatalmak közül Irán mellett Izrael és Törökország aktív résztvevője a konfliktusnak. Izrael nehéz helyzetben van, hiszen egyrészt az ősellenségének tartott Aszadrezsim visszarendeződése nem lehet célja, föként nem az iráni befolyás növekedésével. Másodsorban azonban a dzsihádista felkelők melegágyát adó Idlib sem tekinthető természetes szövetségesének. Törökország ambiciózus célokat táplál Szíriában, amely önmagában túlmutat a szükebb értelemben vett biztonságpolitikai percepción. Ankara hosszabb távon gondolkodik a szíriai jelenlétben, amelyben számára is elképzelhető a Moszkva által támogatott politikai átmenet, amely valamilyen típusú hatalommegosztásra kényszeríti rá az Aszad-rezsimet. Kérdés, hogy Oroszország milyen kompromisszumokat fog ráerőltetni az Aszad-rezsimre. A föderalizmus esetleges bevezetését nemcsak Damaszkusz, hanem Törökország és Irán is ellenzi. Oroszország nem rendelkezik olyan gazdasági potenciállal, amely elegendő lenne az újjáépítés magas költségeinek kiegyenlítésére. A nyugati államok azonban politikai eszközöket vetnek be, hogy megakadályozzák az Aszad-rezsimet támogató pénzügyi források Szíriának való juttatását. Az Egyesült Államok számára, akárcsak a GCC-államoknak az újjáépítésben való részvétel kulcsfontosságú feltétele Irán kiszorítása Szíriából. Iránnak ugyan geopolitikai szempontból jelentősen csökkent a befolyása,

50 Conn Hallinan: Erdogan’s Failed Gamble in Syria, [online], 2020. 03. 09. Forrás: Foreign Policy In Focus [2020. 04. 01.]

51 Heydemann: $i . m ., 2$. 
ugyanakkor Moszkva és az Aszad-rezsim támogatásával korántsem lebecsülhető alakítója az eseményeknek. Ebből következően a szíriai konfliktus egy elhúzódó geopolitikai és geoökonómiai konfliktussá válik, amelyet talán kevésbé fognak a harcszíntéren zajló katonai események dominálni.

\section{FELHASZNÁLT IRODALOM}

Almanasfi, Nadine: State-led urban development in Syria and the prospects for effective post-conflict reconstruction, Syria Studies, 11. évf., 2019/1, 58-99. o.

Al-Tamimi, Aymenn Jawad: Idlib and Its Environs. Narrowing Prospects for a Rebel Holdout, [online], 2020. 02. Forrás: The Washington Institute for Near East Policy [2020. 04. 01.]

Asseburg, Muriel - Wimmen, Heiko: Geneva II - A Chance to Contain the Syrian Civil War, [online], SWP Comments 10, 2014. 01. Forrás: Stiftung Wissenschaft und Politik [2020. 04. 01.]

Balanche, Fabrice: Idlib May Become the Next Gaza Strip, [online], Policy Watch 3288, 2020. 03. 26. Forrás: The Washington Institute for Near East Policy [2020. 04. 01.]

Cafarella, Jennifer - Zhou, Jason: Russia’s Dead-end Diplomacy in Syria, [online], Washington, Institute for the Study of War, 2019. 11. Forrás: Understanding War [2020. 04. 01.]

Clausewitz, Carl von: A háborúról, Göttinger Kiadó, Veszprém, 1999.

DAHER, Joseph: The Dynamics and Evolution of UAE-Syria Relations: Between Expectations and Obstacles, [online], Wartime and Post-conflict in Syria, Research Project Report, 2019/14, 2019. 10. 25. Forrás: Robert Schuman Center for Advanced Studies, European University Institute [2020. 04. 01.] DOI: https://doi. org/10.2870/40366

FARES, Qais: The Syrian Constitution: Assad's Magic Wand, [online], 2014 05. 08. Forrás: Carnegie Middle East Center [2020. 04. 01.]

Geneva Conference II: Challenges Faced in Syria and the Region, [online], Arab Center for Research and Policy Studies, Doha, 2014.

Hallinan, Conn: Erdogan's Failed Gamble in Syria, [online], 2020. 03. 09. Forrás: Foreign Policy In Focus [2020. 04. 01.]

Hatahet, Sinan: Russia and Iran: Economic Influence in Syria, [online], Research Paper, Middle East and North Africa Program, 2019. 03. 17. o. Forrás: Chatham House [2020. 04. 01.]

Heydemann, Steven: Beyond Fragility: Syria and the Challenges of Reconstruction in Fierce States, [online], 2018. 06. Forrás: Foreign Policy at Brookings [2020. 04. 01.]

Hinnebusch, Raymond - Zartman, I. William - PARKer-Magyar, Elizabeth - IMAdy, Omar: UN Mediation in the Syrian Crisis: From Kofi Annan to Lakhdar Brahimi, [online], 2016. 03. Forrás: New York, International Peace Institute [2020. 04. 01.]

Hinnebusch, Raymond: The Battle over Syria’s Reconstruction, Global Policy, 11. évf., 2020/1, 113-123. o. DOI: https://doi.org/10.1111/1758-5899.12779

Itani, Faysal: Geo-economics: Russia and Iran in Syria, Syria Studies, 11. évf., 2019/1, 23-31. o.

Kanj, Sultan al: HTS Tries to 'Syrianize', [online] 2019. 08. Forrás: Chatham House [2020. 04. 01.]

Кнатів, Lina: Bashar al-Assad’s Holow Victory, [online], 2020. 01. 17. Forrás: Foreign Affairs [2020. 04. 01.]

LeEuwen, Jan van - VeEN, Erwin van: Turkey in northwestern Syria. Rebuilding empire at the margins, [online], CRU Policy Brief, 2019. 06. Forrás: Clingendael [2020. 04. 01.]

Lister, Charles: Idlib’s Fate Defines Syria’s Future, [online], 2020. 01. 04. Forrás: Asharq Al-Awsat [2020. 04. 01.]

Lund, Aron: From Cold War to Civil War: 75 Years of Russian-Syrian Relations, [online], Ui, 2019/7. Forrás: Swedish Institute of International Affairs [2020. 04. 01.]

LundGren, Magnus: Mediation in Syria: Initiatives, strategies, and obstacles, 2011-2016, Contemporary Security Policy, 37. évf., 2016/2, 273-288 o. DOI: https://doi.org/10.1080/13523260.2016.1192377 
Mardasov, Anton: Is COVID-19 changing Astana allies' dynamics in Syria?, [online], 2020. 03. 31. Forrás: Al-Monitor [2020. 04. 01.]

Mencütek, Zeynep Şahin: The „Rebirth” of a Dead Organization?: Questioning the Role of the Arab League in the „Arab Uprisings” Process, Perceptions, 19. évf., 2014/2, 83-112. o.

More Healthy and Harmonious Society, [online], Syria Times, 2017. 08. 20. Forrás: Syria Times [2020. 04. 01.]

QAdDour, Jomana: The constitutional committee must be part of a holistic Syrian Process, [online], 2019. 11. 26. Forrás: Middle East Institute [2020. 04. 01.]

Ratney, Michael A.: Five Conundrums: The United States and the Conflict in Syria, [online], Strategic Perspectives 32, 2019. 07. Forrás: Institute for National Strategic Studies [2020. 04. 01.]

Russian Draft Proposal for a New Syrian Constitution, [online], 2017. 02. 09. Forrás: The Middle East Media Research Institute [2020. 04. 01.]

The Best of Bad Options for Syriảs Idlib, [online], Middle East Report No. 197, 2019. 03. 14. Forrás: International Crisis Group [2020. 04. 01.]

The Jihadist Factor in Syria’s Idlib: A Conversation with Abu Mohammed al-Jolani, [online], 2020. 02. 20. Forrás: International Crisis Group [2020. 04. 01.]

Ulrichsen, Kristian Coates: Qatar and the Arab Spring. Policy Drivers and Regional Implications, [online], 2014. 09. Forrás: Carnegie Endowment [2020. 04. 01.]

Veen, Erwin van: The Geopolitics of Syria’s Reconstruction: A Case of Matryoshka, Syria Studies, 11. évf., 2019/1, 33-56. o.

Ways Out of Europe’s Syria Reconstruction Conundrum, [online], Middle East Report, No. 209. 2019. 11. 25. Forrás: International Crisis Group [2020. 04. 01.]

United Nations Resolution 2254, [online], 2015. 12. 18. Forrás: United Nations [2020. 04. 01.]

ZIsser, Eyal: The End of the Syrian Civil War. The Many Implications, Middle East Quarterly, Summer 2019, 1-9. o. 